\title{
Faktor-Faktor yang Memotivasi Minat Mahasiswi dalam Berwirausaha di Politeknik Negeri Batam
}

\author{
Rusda Irawati dan Shinta Wahyu Hati, \\ Politeknik Negeri Batam \\ ira@polibatam.ac.id
}

\begin{abstract}
ABSTRAK
Sifat dan karateristik umum wirausaha bisa dimiliki oleh laki-laki atau perempuan. Perempuan potensial untuk melakukan berbagai kegiatan produktif yang menghasilkan dan dapat membantu ekonomi keluarga, dan lebih luas lagi ekonomi nasional. Politeknik Negeri Batam berkomitmen menumbuhkan dan menciptakan budaya kewirausahaan. Pada tiap angkatan terdapat $70 \%$ mahasiswi yang punya potensi dan peluang untuk bisa menjadi calon wirausaha muda yang mandiri di berbagai sektor usaha. Penelitian ini bermaksud untuk mengetahui, Apakah faktor-faktor yang memotivasi mahasiswi untuk menjadi pengusaha dan dapatkah faktor tersebut mempengaruhi keinginan mahasiswi untuk berwirausaha. Jenis penelitian ini adalah explanatory research dan hubungan yang akan ditelaah adalah keberhasilan diri $\left(\mathrm{X}_{1}\right)$, toleransi terhadap resiko $\left(\mathrm{X}_{2}\right)$ dan keinginan untuk merasakan kebebasan dalam bekerja $\left(\mathrm{X}_{3}\right)$ terhadap keinginan untuk menjadi pengusaha (Y). Populasi dalam penelitian ini adalah mahasiswi Politeknik Negeri Batam. Teknik Pengambilan Sampel menggunakan purposive sampling. Kuesioner disebarkan kepada 100 orang mahasiswi dari jurusan rekayasa dan non rekayasa. Hasil uji menunjukkan bahwa variabel keberhasilan diri dan toleransi resiko berpengaruh signifikan sedangkan kebebasan dalam bekerja tidak berpengaruh signifikan terhadap minat berwirausaha.
\end{abstract}

Kata kunci: Faktor-faktor yang memotivasi minat berwirausaha

\section{ABSTRACT}

Man or women have a nature and characterisric of entrepreneurship. Woman has the potential to do any productive activity that produces and help the economy of family and more broadly national economy. Batam State Polytechnic committed cultived and to create entrepreneurship culture. In each semester, there is $70 \%$ female student who had chances and opportunities to be able to become an independent prospective young entrepreneurs in various business sectors. This research purpose to know, what factors that motivated female student to be a young entrepreneurs and can be that factors influence the desire of female students to entrepreneurship. Category of this research is explanatory research and The relation which will be reviewed by is the success of yourself $\left(x_{1}\right)$, tolerance against the risk $\left(x_{2}\right)$ and a desire to feel freedom in working $\left(x_{3}\right)$ against a desire to become entrepreneurs ( $y$ ). Population in this research is a student of Batam State Polytechnic. The sampling technique is purposive sampling. A questionnaire distributed to 100 female students from the Department of engineering and non-engineering. The results showed that success of the self 
and the variable tolerance of risk significant effect, while the freedom in work do not affect significantly the interest of entrepreneurship.

Keywords: The factors that motivate the interest of entrepreneurship

\section{PENDAHULUAN}

Faktor ekonomi yang mempengaruhi pertumbuhan dan pembangunan ekonomi diantaranya adalah sumber daya alam, sumber daya manusia, sumber daya modal, dan keahlian atau kewirausahaan. Saat ini, Jumlah penduduk Indonesia yang bekerja sebagai Entrepreneur (wirausahawan) hanya naik 1,56 persen dalam tiga tahun, per Januari 2012. Bila dibandingkan Malaysia dan Singapore, Indonesia masih sangat jauh tertinggal. Pembangunan akan lebih berhasil jika ditunjang oleh para entrepreneur yang dapat membuka lapangan kerja karena kemampuan pemerintah sangat terbatas.

Perempuan potensial untuk melakukan berbagai kegiatan produktif yang menghasilkan dan dapat membantu ekonomi keluarga, dan lebih luas lagi ekonomi nasional, apalagi potensi tersebut menyebar di berbagai bidang maupun sektor. Dengan potensi tersebut perempuan potensial berperan aktif dalam proses recovery ekonomi.

Politeknik Negeri Batam yang merupakan salah satu perguruan tinggi di Kota Batam dan telah berstatus negeri memiliki peran untuk berkomitmen menumbuhkan dan menciptakan budaya kewirausahaan. Sesuai dengan Renstra Politeknik Negeri Batam berupaya mewujudkan kemandirian, adapun strategi yang bisa dicapai adalah mendorong munculnya inkubator bisnis, memfasilitasi berbagai upaya untuk menumbuhkan jiwa kewirausahaan di kalangan mahasiswa.

Dari data yang diperoleh bahwa mahasiswa yang saat ini sedang menempuh pendidikan hampir 70\% dari setiap angkatan adalah berjenis kelamin perempuan. Mahasiswa perempuan ini punya potensi dan peluang untuk bisa menjadi calon wirausaha muda yang mandiri di berbagai sektor usaha baik itu usaha manufaktur, dagang, jasa, dan kemaritiman.

Dalam penelitian ini terdapat batasan masalah guna memfokuskan pada masalah yang akan di teliti dimana faktor-faktor Yang memotivasi mahasiswa untuk menjadi pengusaha dapat mempengaruhi keinginan mahasiswa untuk berwirausaha. Tujuan dalam penelitian ini meliputi;

a. Untuk menganalisis pengaruh motivasi keberhasilan diri menjadi pengusaha terhadap keinginan mahasiswi untuk berwirausaha.

b. Untuk menganalisis pengaruh motivasi toleransi akan resiko seorang mahasiswi terhadap keinginannya untuk berwirausaha.

c. Untuk menganalisis pengaruh motivasi merasakan kebebasan dalam bekerja terhadap keinginan mahasiswi untuk berwirausaha.

\section{METODE PENELITIAN}

Jenis penelitian ini adalah explanatory research, yaitu penelitian yang bertujuan untuk menelaah hubungan kausal antar variabel melalui pengujian hipotesis yang ditetapkan sebelumnya. Dalam hal ini, hubungan yang akan ditelaah adalah keberhasilan diri $\left(\mathrm{X}_{1}\right)$, toleransi terhadap resiko $\left(\mathrm{X}_{2}\right)$ dan 
keinginan untuk merasakan kebebasan dalam bekerja $\left(\mathrm{X}_{3}\right)$ terhadap keinginan untuk menjadi pengusaha (Y).

Populasi dalam penelitian ini adalah mahasiswa perempuan (mahasiswi) Politeknik Negeri Batam. Teknik Pengambilan Sampel dalam penelitian ini menggunakan purposive sampling. Pada teknik ini sampel sudah ditentukan kriterianya yaitu mahasiswa perempuan (mahasiswi) yang sedang menempuh pendidikan di semester 2 berjumlah 100 orang dari jurusan rekayasa dan non rekayasa.

Untuk memperoleh data primer yang diperlukan, teknik yang digunakan adalah pengisian kuesioner. Dalam penelitian ini kuesioner menggunakan pertanyaan tertutup dan terbuka dan disebarkan kepada 100 orang responden mahasiswi.

Metode analisis data menggunakan statistik deskriptif dan statistik inferensial. Untuk menguji hubungan antar variabel dalam penelitian ini, digunakan rumus Analisi Regresi berganda sebagai berikut (Supranto, 2009):

$$
Y_{i}=b_{0}+b_{1} X_{1 i}+b_{2} X_{2 i}+\ldots+b_{k} X_{k i}+e_{i}
$$

Untuk pengujian hipotesis tentang koefisien regresi parsial, digunakan kriteria uji t dengan rumus sebagai berikut (Supranto, 2009):

$t_{0}=\frac{b_{j}-B_{j 0}}{S_{b_{i}}}$

$t_{0}$ mempuny aifungsi $\mathrm{t}$ dengan derajat kebebasan sebesar $\mathrm{n}-\mathrm{k}-1$

$S_{b_{i}}=S_{e} \sqrt{d_{j j}}$ dan $S_{\mathrm{e}}=\sqrt{\frac{1}{n-k-1} \sum e_{i}^{2}}$

\section{HASIL PENELITIAN}

\section{a. Deskripsi Responden}

Responden pada penelitian ini adalah mahasiswi Politeknik Negeri Batam yang berasal dari empat jurusan, yaitu Teknik Mesin, Teknik Elektro, Teknik Informatika dan Manajemen Bisnis.

Beberapa item pertanyaan yang diajukan untuk mengetahui identitas responden adalah usia, angkatan di kampus, jurusan, pernah memiliki pengalaman merasa kehilangan atau merasa rugi yang bersifat materi, anak ke berapa dalam keluarga, asal daerah, pekerjaan orang tua, harapan sebagai seorang wanita berikut alasannya dan cita-cita seandainya jadi pengusaha.

1. Umur Responden

Usia responden hanya masuk dalam dua kategori, yaitu 18-21 tahun sebanyak 99\% dan 22-25 tahun sebanyak $1 \%$.

2. Angkatan

Dari jawaban responden diketahui bahwa, $81 \%$ responden bergabung sebagai mahasiswa pada tahun 2012 dan 17\% selain angkatan 2011 dan 2012. Sisanya 2\% berasal dari mahasiswi angkatan 2011.

3. Jurusan

Mahasiswi yang dijadikan responden dalam penelitian ini berasal dari empat jurusan, mahasiswi jurusan Manajemen Bisnis adalah responden terbesar, dengan 
jumlah $64 \%$. Berikutnya mahasiswi dari jurusan Teknik Informatika 21\%, diikuti dengan mahasiswi jurusan Teknik Elektro $13 \%$ dan sisanya mahasiswi dari jurusan Teknik Mesin $2 \%$.

4. Pengalaman Kehilangan/Rugi

Pernah merasa kehilangan atau rugi yang bersifat materi perlu dirasakan oleh seorang wirausaha. Hal ini berkaitan dengan karakter yang tidak gampang menyerah dalam menjalani suatu usaha kelak. $42 \%$ responden belum pernah merasa kehilangan/rugi dan 58\% responden pernah mengalami rugi atau kehilangan yang bersifat materi. Frekuensi kehilangan atau rugi, ketika ditanyakan kepada responden berkisar antara 1-lebih dari 10 kali bahkan ada yang menjawab sering.

5. Urutan dalam Keluarga

Dari jawaban responden diketahui bahwa 49 orang responden merupakan anak pertama dalam keluarganya. 27 orang responden adalah anak kedua, 10 orang responden adalah anak ketiga, 7 orang responden adalah anak ke empat dan 7 orang responden adalah anak diurutan selain itu.

6. Asal Daerah

Responden yang berasal dari Batam (kelahiran Batam) adalah 54 orang. Sedangkan yang berasal dari luar Batam adalah sebanyak 46 orang.

7. Pekerjaan Orang Tua

Terdapat tiga kategori jawaban untuk pekerjaan orang tua responden, pengusaha, pegawai negeri sipil dan pegawai swasta. Dari hasil jawaban yang diberikan oleh responden, hanya $15 \%$ responden yang orang tuanya adalah pengusaha. $21 \%$ responden menjawab bahwa pekerjaan orang tuanya adalah PNS. Sisanya 64\% orang tua responden bekerja sebagai pegawai swasta

8. Harapan untuk Maju

Adapun hasil jawaban yang diperoleh dari responden adalah $100 \%$ responden menjawab ya (punya harapan untuk maju) Tidak terdapat responden yang menjawab "tidak punya harapan untuk maju atau "biasa saja". Alasan yang diberikan oleh responden sangat beragam, antara lain: ingin jadi wanita yang mandiri, agar tidak diremehkan laki-laki, ingin hidup lebih baik, ingin lebih maju/sukses, emansipasi wanita, ingin mewujudkan impian, ingin berhasil dalam segala bidang, karena wanita punya potensi yang sama dengan pria, membahagiakan orang tua, membantu keluarga, mewujudkan cita-cita, untuk berjuang, perlu mengikuti kemajuan dan perkembangan zaman, ingin mengubah dunia dan semua orang ingin sukses.

9. Cita-Cita

Seandainya jadi pengusaha, responden bercita-cita mempunyai usaha dalam bidang manufaktur 12 orang, jasa 16 orang, perdagangan 16 orang, industri kreatif 20 orang dan usaha kuliner dengan pilihan terbanyak yaitu 35 orang. Sedangkan 1 orang responden tidak memberikan jawaban.

\section{b. Hasil Uji Statistik Inferensial}

Hasil perhitungan korelasi dapat diketahui bahwa koefesien determinasi (adjusted R) yang diperoleh 16,3\% yang dipengaruhi oleh variabel keberhasilan diri, toleransi pada resiko dan kebebasan dalam bekerja, sedangkan $81,00 \%$ dipengaruhi dan dijelaskan oleh variabel yang lain.

Tabel Hasil Koefesien Determinasi 
Model Summary

\begin{tabular}{|l|r|r|r|r|}
\hline Model & R & R Square & $\begin{array}{c}\text { Adjusted } \\
\text { R Square }\end{array}$ & $\begin{array}{c}\text { Std. Error } \\
\text { of the } \\
\text { Estimate }\end{array}$ \\
\hline 1 & $.404^{\mathrm{a}}$ & .163 & .137 & .4129762 \\
\hline
\end{tabular}

Predictors: (Constant), kebebasan dalam bekerja, keberhasilan diri, toleransi akan resiko

\section{c. Hasil Uji Regresi Berganda}

\begin{tabular}{|l|l|c|c|c|c|}
\hline $\begin{array}{c}\text { Variabel } \\
\text { Dependen }\end{array}$ & $\begin{array}{l}\text { Varibel } \\
\text { Independent }\end{array}$ & $\mathrm{B}$ & $\mathrm{t}$ & $\mathrm{Sig}$ & Pengaruh \\
\hline $\begin{array}{l}\text { Motavasi } \\
\text { Berwiraus } \\
\text { aha }\end{array}$ & $\begin{array}{l}\text { Keberhasilan } \\
\text { diri (X1) }\end{array}$ & 0,261 & $\begin{array}{l}3,34 \\
0\end{array}$ & $\begin{array}{l}0,00 \\
1\end{array}$ & signifikan \\
\cline { 2 - 6 } & $\begin{array}{l}\text { Toleransi } \\
\text { resiko (X2) }\end{array}$ & 0,336 & $\begin{array}{l}3,83 \\
5\end{array}$ & $\begin{array}{l}0,00 \\
0\end{array}$ & Signifikan \\
\cline { 2 - 6 } & Kebebasan & 0,047 & $\begin{array}{l}0,57 \\
8\end{array}$ & $\begin{array}{l}0,56 \\
4\end{array}$ & $\begin{array}{l}\text { Tidak } \\
\text { Signifikan }\end{array}$ \\
& Dalam & & 8 & & \\
\hline & Bekerja (X3) & & & & \\
\cline { 2 - 6 } & Uji -F & 6,233 & \multicolumn{4}{|l}{} \\
\hline
\end{tabular}

Berdasarkan hasil uji $-\mathrm{F}$, model menunjukkan nilai $\mathrm{F}$ sebesar 6,233 dengan probabilitas sebesar 0,001. Nilai signifikansi tersebut lebih kecil dari 0,050. Bisa disimpulkan bahwa uji variabel secara serempak yaitu variabel keberhasilan diri (X1), Toleransi resiko (X2) dan Kebebasan dalam bekerja (X3) pada motivasi minat berwirausaha dapat dijelaskan.

Hasil yang diperoleh dari regresi berganda bahwa variabel tersebut memiliki koefesien regresi dengan arah positif. Hasil uji t menunjukkan bahwa seberapa jauh pengaruh satu variabel independen secara individual dalam menerangkan variasi dependen. Masing-masing variabel menunjukkan bahwa variabel keberhasilan diri dan toleransi resiko berpengaruh signifikan sedangkan kebebasan dalam bekerja tidak berpengaruh signifikan. Model persamaan regresi yang dapat dituliskan dari hasil tersebut adalah dalam bentuk persamaan regresi sebagai berikut

$$
Y=2.440+0,261 X_{1}+0,336 X_{2+} 0,047 X_{3}
$$

\section{1). Keberhasilan Diri $\left(\mathbf{X}_{1}\right)$}

Hasil pegolahan data menunjukkan bahwa mahasiswa memberikan tanggapan yang positif. Mahasiswa memberikan tanggapan merasa memiliki semangat dalam bekerja yang tinggi dengan tanggapn sangat setuju sebesar $39,00 \%$, jawaban setuju sebesar $54 \%$, biasa saja sebesar $6,00 \%$ dan tidak ada yang menjawab sangat tidak setuju.

Mahasiswa memberikan tanggapan perlu melakukan sesuatu untuk mencapai suatu tujuan yang telah ditetapkan. Mahasiswa member tanggapan bahwa mahasiswa merasa termasuk golongan orang yang optimis dalam mengerjakan sesuatu sesuai target dengan jawaban sangat setuju sebesar 25, 00\%, Jawaban setuju $52,00 \%$, biasa saja sebesar $22,00 \%$ dan jawaban sangat setuju hanya $1,00 \%$. Mahasiswa menyatakan sangat setyuju $21,00 \%$ setuju $47,00 \%$ 
biasa saja $29,00 \%$ sebagai orang yang tekun, ulet dan dapat dihandalkan dan hanya $3,00 \%$ yang member tanggapan tidak setuju.

Mahasiswa membri tanggapan sangat setuju bahwa mereka merasa memiliki kompetensi yang cukup untuk bersaing denga orang lain dalam dunia kerja, dengan tanggapan sangat setuju sebesar $15,00 \%$, setuju sebesar 35,00\% dan tanggapan mahasiswa $45,00 \%$ biasa saja.

Bisa disimpulkan variabel keberhasilan adalah positif yang ditunjukkan dengan nilai mean 4,13 .

\section{2). Toleransi akan Resiko $\left(\mathrm{X}_{2}\right)$}

Hasil dari pengolahan data menunjukkan bahwa tanggapan responden pada toleransi resiko yang diukur dengan item pertanyaan adalah sebagai berikut; untuk menghadapi resiko yang akan diambil. Mahasiswi merasa termasuk orang yang memiliki rasa tanggungjawab yang besar dalam melaksanakan keputusan yang diambil sebesar $40.00 \%$ menyatakan sangat setuju $45,00 \%$ setuju 13,00 biasa saja, tidak setuju $2,00 \%$ dan yang menjawab sangat tidak setuju tidak ada.

Tanggapan mahasiswi merasa termasuk orang yang suka terhadap tantangan, adapaun mahasiswa yang memberi tanggapan sangat setuju sebesar $34,00 \%$ mahasiswi menyatakan setuju sebesar 48,00\% mahasiswi yang menyatakan biasa saja sebesar $15,00 \%$ mahasiswa yang menyatakan tidak setuju $2,00 \%$ dan mahasiswa yang menyatakan sangat tidak setuju sebesar $1,00 \%$. Mahasiswi memberikan tanggapan sebagai tergolong orang yang sabar dalam mengatasi berbagai masalah, mendapat respon sangat setuju sebesar $26,00 \%$ tanggapan setuju sebesar 43,00\% tanggapan biasa saja sebesar 27,00\% tanggapan tidak setuju 3,00\% dan jawabana sangat tidak setuju sebesar $1,00 \%$.

Mahasiswi memberikan tanggapan sangat setuju sebesar $25,00 \%$ setuju sebesar 46,00\% menyatakan biasa saja sebesar 24,00\% tidak setuju sebesar 4,00\% dan sangat tidak setuju sebesar $1,00 \%$ bahwa termasuk orang yang suka mengambil kesempatan-kesempatan untuk mengembangkan diri sebesar. Kesimpuilan pada variabel ini bisa dikatakan mendapat tangapan posisitf yaitu ditunjukkan pada nilai mean sebesar 4,01

\section{3). Kebebasan dalam Bekerja $\left(X_{3}\right)$}

Tanggapan responden terhadap variabel kebebasan dalam bekerja dilihat dari indicator sebagai berikut responden atau mahasiswi merasa suka memberontak terhadap kekuasaan sebesar mendapat tanggapan sangat setuju sebesar $11,00 \%$ setuju $22,00 \%$ tanggapan biasa saja 24,00\% tidak setuju $26,00 \%$ dan tanggapan sangat tidak setuju sebesar 7,00\%. Tanggapan mahasiswi merasa suka berfikir kritis dan berpendapat terhadap suatu kebijakan sebesar mendapat tanggapan sangat setuju sebesar $13,00 \%$ setuju $51,00 \%$ tanggapan bioasa saja $31,00 \%$ tanggapan tidak setuju sebesar $4,00 \%$ sedangkan yang menjawab sangat tidak setuju sebesar $1,00 \%$. Tanggapan mahasiswi terhadap item pertanyaan bahwa mahasiswi merasa senang mengambil prakarsa atau inisiati mendapat tanggapan sangat setuju sebesar $17,00 \%$ tanggapan setuju sebesar 54,00\% tanggapan biasa saja 19,00\%. tanggapan tidak setuju sebesar $2,00 \%$ dan tidak ada tanggapan sangat tidak setuju.

Mahasiswa terkadang bersikap keras kepala dalam mempertahankan pendapat mendapat tanggapan sangat setuju sebesar $21,00 \%$ tanggapan setuju 
sebesar 49,00\% tanggapan bisa saja sebesar 19,00\% tanggapan 10,00\% tidak setuju dan 2,00\% sangat tidak setuju. Mahasiswi merasa terkadang bersikap keras kepala dalam mencapai tujuan sebesar mendapat tanggapan $18,00 \%$ sangat setuju $51,00 \%$ setuju $19,00 \%$ b tanggapan tidak setuju sebesar $10,00 \%$ dan sangat tidak setuju sebesar 2,00\%. Mahasiswi bersikap keras kepala dalam mempertahankan sebuah prinsip mendapat tanggapan sangat setuju sebesar $22,00 \%$ tanggapan setuju sebesar 55,00\% tanggapan biasa saja sebesar 13,00\% tanggapan tidak setuju sebesar 3,00\% dan tanggapan sangat tidak setuju sebesar 3,00\% dan tanggapan sangat tidak setuju sebesar 3,00\%.

Tanggapan mahasiswi terhadap kebebasan pribadi adalah sangat penting mendapat tangggapan sangat setuju sebesar 38,00\% tanggapan setuju sebesar $43,00 \%$ tanggapan biasa saja sebesar $13,00 \%$ tidak setuju sebesar $3,00 \%$ dan sangat tidak setuju hanya 3,00\% Mahasiswa cenderung mengikuti bisikan nurani (bersifat intuisi) mendapat tanggapan sangat setuju sebesar $25,00 \%$ jawaban setuju sebesar $42,00 \%$ tanggapan biasa saja sebesar $26,00 \%$ tanggapan tidak setuju sebesar 4,00\% dan jawaban sangat tidak setuju sebesar 3,00\%.

\section{4). Motivasi Minat Berwirausaha (Y)}

Tanggapan responden terhadap variabel motivasi berwirausaha diukur dengan menggunakan item pertanyaan sebagai berikut. Mahasiswa termasuk orang yang percaya diri dalam bertindak sebesar mendapat tanggapan sangat setuju sebesar $22,00 \%$ tanggapan setuju sebesar 46,00\% tanggapan biasa saja sebear $28,00 \%$ tanggapan tidak setuju sebesar $4,00 \%$ dan tidak ada yang menanggapia sangat tidak setuju.

Mahasiswi merasa selalu berfikir selalu berfikir inovatif dan kreatif mendapat tanggapan sangat setuju sebesar $14,00 \%$ tanggapan setuju sebesar $49,00 \%$ biasa saja sebesar 35,00\% tidak setuju sebesar 2,00\% dan tidak ada yang memberikan tanggapan sangat tidak setuju. Mahasisw selalu tertarik pada posisi kepemimpinan mendapat respon tanggapan sebesar 40,00\% sangat setuju 47,00\% tidak setuju $23,00 \%$ biasa saja dan $2,00 \%$ tidak setuju dan tidak ada yang memberikan tanggapan sangat tidak setuju.

Mahasiswa senang menjalani hidup secara efektif dan efisien mendapat tanggapan sangat setuju sebesar 40,00\% tanggapan setuju sebesar 49,00\% tanggapan biasa saja 24,00\% dan tanggapan tidak setuju sebesar $1,00 \%$ sedangkan tanggapan sangat tidak setuju stidak ada. Mahasiswa bisa berupaya menyelesaikan tugas dan pekerjaan secara efektif dan efesien mendapat tanggapan sangat setuju sebesar 30,00\% setuju sebesar 63,00\% tanggapan biasa saja sebesar 6,00\% tanggapan tidak setuju hanya $1,00 \%$ dan tidak ada yang menjawab sangat tidak setuju. Mahasiswa merasa selalu berorientasi pada masa depan dalam merencanakan sesuatu sebesar mendapat tanggapan sangat setuju sebesar $23,00 \%$ setuju sebesar $41,00 \%$ Biasa saja 33,00\% tidak setuju sebesar 2,00\% dan sangat tidak setuju sebesar $1,00 \%$. Mahasiswa merasa tidak mudah berputus asa bila ada kegagalan mendapat tanggapan sangat setuju sebesar $47,00 \%$ setuju sebesar $34,00 \%$ tanggapan biasa saja sebesar $13,00 \%$ tanggapan tidak setuju sebesar $6,00 \%$ dan tidak ada yang menjawab sangat tidak setuju. Mahasiswi selalu berupaya untuk meningkatkan kualitas pekerjaan sangat setuju sebesar $47.00 \%$ setuju $34,00 \%$ biasa saja $13,00 \%$ tidak setuju $6,00 \%$ dan tidak ada yang menjawab sangat tidak setuju. 


\section{PEMBAHASAN}

Hipotesis 1 menunjukkan ada pengaruh positif dan signifikan. Nilai koefsien regresi sebesar 26,10\%, sedangkan 73,9\% dipengaruhi yang lain. Bisa dikatakan bahwa ada keberhasilan diri bisa berpengaruh positif terhadap motivasi keinginan mahasiswi dalam berwirausaha. Mahasiswi wanita memiliki semangat bekerja yang tinggi, mahasiswa melakukan sesuatu untuk mencapai tujuan yang telah ditetapkan oleh individu mahasiswa itu sendiri. Mahasiswi juga merasa termasuk golongan yang optimis dalam mengerjakan sesuatu sesuai dengan target. Mahasiswi merasa adalah orang yang tekun, ulet dan dapat diandalkan dalam bekerja. Mahasiswi merasa sudah memiliki kompetesni yang cukup untuk bersaing dengan orang lain.

Hasil penelitian menunjukkan bahwa mahasiswa memiliki semangat keberhasilan diri, semangat diri untuk berhasil merupakan karakter dan ciri khas wirausaha. Temuan hasil penelitian ini sesuai dengan teori dari Atkitson (2004) menyatakan bahwa salah satu faktor penting dan menjadi daya penggerak bagi seseorang untuk menjadi entrepreneur adalah keinginannya untuk memenuhi kebutuhannya untuk berhasil serta menjauhi kegagalan.

Temuan penelitian ini sesuai dengan hasil penelitian Darmadji (2002) tetang sikap kemandirian dalam mempengaruhi motivasi berwirausaha.

Hipotesis 2 menunjukkan ada pengaruh positif dan signifikan dengan nilai koefesien regresi sebesar 33,6\%, sedangakan sisanya 66,4\% dapat dipengaruhi yang lain. Bisa Dikatakan toleransi akan resiko untuk berwirausaha berpengaruh positif. Mahasiswi selalu berfikir panjang untuk menghadapi resiko yang akan diambil, mahasiswa memiliki rasa tanggung jawab yang besar dalam melaksanakan keputusan, mahasiswi termasuk orang yang enyukai tantangan. Mahaiswi termasuk orang yang sabar dalam mengatasi berbagai masalah. Mahasiswi termasuk orang yang suka mengambil kesempatan -kesempatan untuk mengembangkan diri.

Pilihan berwirausaha tentunya akan ada resiko yang ditanggung resiko materi atau finansial, resiko kehilangan waktu, resiko kehilangan kesempatan. Disini mahasiswi dituntut harus memiliki rasa tanggung jawab yang besar dalam melaksanakan kewajiban. Mahasiswi dituntut kesabarannya dalam menghadapi berbagai resiko yang diambil. Temuan hasil penelitian ini sesuai dengan Menurut Suryana (2003) seorang entrepreneur harus mampu mengambil resiko yang moderat, artinya resiko yang diambil tidak terlalu tinggi dan tidak terlalu rendah. Keberanian menghadapi resiko yang didukung komitmen yang kuat, akan mendorong seorang entrepreneur untuk terus berjuang mencari peluang sampai memperoleh hasil.

Hipotesis 3 menunjukkan ada pengaruh positif dan tidak signifikan dengan nilai koefesien regresi sebesar $4,7 \%$ saja. Tanggapan mahasiswa sangat rendah Mahasiswi biasa memberontak terhadap kekuasaan, mahasiswi suka berfikir kritis dan berpendapat terhadap suatu kebijakan, mahasiswi senang mengambil prakarsa atau inisiatif, mahasiswi bersikap keras dalam mempertahankan pendapat dan mencapai tujuan. Mahasiswi bersikap keras dalam mempertahankan sebuah prinsip.Mahasiswi memiliki kebebasan pribadi dan cenderung mengikuti bisikan nurani. 
Bisa dikatakan kebebasan dalam bekerja tidak bisa direspon positif oleh mahasiswa. Batam sebagai kota industry ternyata sangat mempengaruhi motivasi mahasiswi dalam berwirausaha. Kebutuhan tenaga kerja wanita di Kota Batam sangat besar terutama untuk tenaga yang bergelar lulusan diploma. Menurut data Jumlah pencari kerja di Batam didominasi kelompok perempuan sebanyak 18.280 jiwa. Sedangkan kelompok pria tercatat 11.812 jiwa.

Batam sebagai kota industry masih sangat menjanjikan bagi para mahasiswi untuk memilih bekerja dari pada berwirausaha.

Hasil uji secara serempak menunjukkan positif dan signifikan tetapi sangat rendah. Hasil perhitungan korelasi menunjukkan bahwa koefesien determinasi (adjusted R) yang diperoleh 16,3\% yang dipengaruhi oleh variabel keberhasilan diri, toleransi pada resiko dan kebebasan dalam bekerja, sedangkan 81,00\% dipengaruhi dan dijelaskan oleh variabel yang lain. Bisa disimpulkan bahwa mahasiswi cukup berminat untuk berwirausaha

\section{KESIMPULAN}

\section{Kesimpulan}

Kesimpulan dalam penelitian ini adalah sebagai berikut:

1. Keberhasilan diri memiliki pengaruh positif dan signifikan terhadap motivasi mahasiswa perempuan dalam berwirausaha. Keberhasilan diri yang lebih besar yang diperoleh mahasiswi dapat meningkatkan motivasi dalam berwirausaha

2. Toleransi akan resiko memiliki pengaruh positif dan signifikan terhadap minat atau motivasi mahasiswi dalam berwirausaha. Toleransi yang besar terhadap resiko akan berpengaruh terhadap motivasi dalam berwirausaha

3. Kebebasan melakukan pekerjaan memiliki pengaruh positif dan tidak signifikan terhadap motivasi mahasiswi dalam berwirausaha, maka bisa dikatakan tidak ada pengaruh yang signifikan. Bisa diambil kesimpulan bahwa kebebasan belum memberikan dorongan mahasiswi untuk memutuskan berwirausaha.

\section{DAFTAR RUJUKAN}

Aditya Dion Mahesa dan Edy Rahardja, 2012, Analisis Faktor-Faktor Motivasi yang Mempengaruhi Minat Berwirausaha, Diponegoro Journal of Management, Vol 1 No 1 Tahun 2012

Anonymouse .2011 Badan Pusat Statistik Kota Batam

Bank Dunia, 2002, Pembangunan Berspektif Endenering Development Melalui Perspektif Gender dalam Hak Sumberdaya dan Aspirasi. Laporan Penelitian Bank Dunia. Dian Rakyat. Jakarta

Berglund and Wennberg. 2006 Creativity among entrepreneurship students: comparing engineering and business education Journal Engineering Education and Lifelong Learning, Vol. 16, No. 5, 2006

Buchari Alma, 2009, Kewirausahaan untuk Mahasiswa dan Umum, Penerbit Alfabeta, Bandung

David McClelland, 2008, The Achieving Society, The Free Press Division of Mac. Millan Publishing, New York 
Douglas Evan. J \& Shepherd, Dean A. (2002) Self-employment as a Career Choice: Attitudes, Entrepreneurial Intentions, and Utility Maximization. Entrepreneurship Theory and Practice, jounal article, http://eprints.qut.edu.au/5527/

Ghozali, Imam. 2007. Manajemen Resiko. Badan Penerbit Universitas Diponegoro. Semarang

Hendro. 2005. How to become a smart entrepreneur and to start a new business. Penerbit Adi. Yogyakarta.

Herman.2007. Manajemen Resiko. Bumi Aksara. Jakarta

Ika Putra dan Kurnianto Sad. 2012. Menumbuhkan Kembangkan Minat Berwirausaha Bagi Para Mahasiswa di Lingkungan Perguruan Tinggi Prosiding Seminar \& Konferensi Nasional Manajemen Bisnis, $26 \mathrm{Mei}$

Indriantoro Nur dan Bambang Supomo. 2002. Metodologi Penelitian Bisnis untuk Akuntansi dan Manajemen, Edisi Pertama, BPFE-Yogyakarta, Yogyakarta

J. Supranto. 2009. Statistik Teori dan Aplikasi, Edisi Ketujuh, Penerbit Erlangga, Jakarta

Kiyosaki, Robert. 2008. The Cashflow Qudrant. Gramedia Pustaka Utama. Jakarta.

Linda, Tee Suan dan Yeow, Jian Ai dan Raman, Kavitha dan Koe, Wei Loon dan Tanumihardja, Joenathan (2011) entrepreneurial intentions among university students / Chin Tee Suan ... [et al.]. Business Management Quarterly Review, 2 (3) . pp. 33-38. ISSN 2180-2777

Muiz, Niam. 2006. Entrepreneur Milenium. Penerbit Galia Indonesia. Bogor.

Rohayatien, Rakib, Towaf, Sutatmi.2011 Program Pendidikan Wirausaha Berwawasan Gender Berbasis Jasa Boga di Pesantren Salaf Jurnal Ekonomi Bisnis, TH. 16, NO. 1, Maret 2011

Susanto, Adi. 2000. Kewirausahaan. Ghalia Indonesia. Jakarta.

Vemy.2012.Faktor-faktor yang mempengaruhi Intensi Berwirausaha siswa SMK Jurnal Pendidikan Vokasi, Vol 2, Nomor 1, Februari 2012

Winardi, J. 2004. Entrepreneur dan Entrepreneurship. Prenada Media. Jakarta 